Article

\title{
Creating a Sustainable Education Environment with Augmented Reality Technology
}

\author{
Damla Karagozlu ${ }^{1,2}$ (D)
}

1 Department of Computer Information Systems, Near East University, Nicosia 99138, Cyprus; damla.karagozlu@neu.edu.tr

2 Computer Information Systems Research and Technology Centre, Near East University, Nicosia 99138, Cyprus

Citation: Karagozlu, D. Creating a Sustainable Education Environment with Augmented Reality Technology. Sustainability 2021, 13, 5851. https:// doi.org/10.3390/su13115851

Academic Editor: Jorge Martin Gutierrez

Received: 27 April 2021

Accepted: 20 May 2021

Published: 23 May 2021

Publisher's Note: MDPI stays neutral with regard to jurisdictional claims in published maps and institutional affiliations.

Copyright: (C) 2021 by the author. Licensee MDPI, Basel, Switzerland. This article is an open access article distributed under the terms and conditions of the Creative Commons Attribution (CC BY) license (https:// creativecommons.org/licenses/by/ $4.0 /)$.

\begin{abstract}
As the COVID-19 epidemic caused new requirements in education, the use of various technologies and materials in science education has gained more importance for sustainability. Among other objectives, the subject of science aims to help students gain skills such as identifying problems, doing research, forming hypotheses, completing experiments, conducting analyses, and reporting the findings. Some of the problems experienced in science education are caused by the lack of tools and equipment. Through augmented reality (AR), a developing technology that is also used in the field of education, a digital layer is superimposed over authentic world images. The main aim of this study is to determine the views of students and teachers regarding augmented reality content developed for science education. The study group consists of 80 seventh-grade students and 4 science teachers. The study adopted a qualitative data collection method so the researchers developed and used semi-structured interview forms for the students and the teachers during the interviews. Both the students and the teachers reported the positive effects of AR practices on improving the understanding of science topics, offering a visual topic introduction, and contributing to the in-class interaction during class hours.
\end{abstract}

Keywords: augmented reality; science education; design-based learning model

\section{Introduction}

Science includes studies on examining and explaining living creatures and events, making generalizations with principles regarding these, and trying to predict future events through these principles. Similarly, the subject of science that is taught in schools studies creatures and events in nature. The content of science education includes information on different forms such as phenomenon, concepts, principles, and generalizations, theories, and laws of nature [1].

The aim of science education is to help students make descriptions of the environment in relation to life, physics, and earth sciences. Science education also teaches students skills such as stating problems, questioning, investigating, doing research, forming hypotheses, conducting experiments, analyzing collected data, and reporting the findings through scientific methods [2].

The effectiveness and permanence of science education depend on the method, technique, and materials used in the lessons. Methods, techniques, and materials that address as many sensory organs as possible and are appropriate for the students' level positively affect the permanence and efficiency of science education. In this sense, methods and materials that enable students to practice, require cognitive skills, and support learning through experience should be preferred in science education lessons [3].

However, what is expected from the students in schools with traditional methods is memorizing information presented to them without taking on an active role in the learning process $[4,5]$. The problems faced regarding science education are teaching methods and techniques, teaching programs, lack of tools and equipment, and teacher characteristics [6]. 
On the other hand, Ünal and Ergin [7] stated that lessons not supporting learning by doing and learning through experience are the reason that science education fails and students have negative attitudes toward it.

Considering the emergence of technology and its use in education, many elements of technology have been included and adopted in the educational learning process [8]. Sustainable education can be provided in environments developed to include a variety of learning resources that allow students to easily acquire information [9]. Although the existing traditional teaching methods used in education work effectively in certain cases, teaching and learning have been affected positively by the changeover caused by the integration of technology [10]. Augmented reality (AR) is a developing technology and a tool used in education, where a digital layer is superimposed over real-world images. Augmented reality is a technology where reality, audio, video, graphics, and GPS location data prepared on computers are combined with the real world [11].

When the use of AR technology in learning settings is reviewed, it is seen to have many advantages. It was observed that the use of AR technology positively affects students' active participation in learning activities and their attention span [12]. In addition to this, Wu et al. [13] suggested that the use of AR in educational settings offers the content in a three-dimensional perspective, provides simultaneous and collaborative learning opportunities, and makes what is invisible become visible. Among other benefits, AR technologies also have a positive impact on students' academic success and their interest in the subject matter [14].

There is a significant increase in the integration of AR in different disciplines of education. The two cases for the best implementation of AR are phenomena or situations that cannot be simulated in reality [15] and situations where real experiences are dangerous and with obvious deficiencies [16]. Science education is one of the disciplines where AR can be implemented due to the abstract concepts it includes and students' need to form cognitive models during the lessons [17].

There are several related studies on the use of AR technology for science education in the literature. Sahin and Yilmaz [18] aimed to determine the impact of learning content developed through AR technology on secondary school students' success and attitudes towards the science subject and students' attitudes towards AR practices. A quasi-experimental design method where a total of one hundred 7th grade students from two different schools were randomly assigned to two groups as the experiment or the control group. The experiment group used AR technology and the control group used traditional methods and course books to complete the same module. It was seen that the students from the experiment group had a higher success rate and more positive attitudes toward the subject.

Similarly, Karagozlu, Kosarenko, Efimova, and Zubov [19] conducted a study to investigate students' attitudes towards the AR content developed for science education. In the study which adopted a quantitative data collection method, the data was collected through the attitude scale for augmented reality applications. The findings showed that the students were satisfied with the AR applications, found them interesting and easy to use, and wished to use them in the future.

In another study, Georgiou and Kyza [20] focused on the effects of immersion on learning outcomes and motivation within the framework of location-based AR settings. A total of 135 tenth-grade students who used the AR application for environmental science learning participated in the study. The findings of the study indicated that there is a considerable amount of improvement in students learning outcomes in terms of conceptual input due to their location-based AR activity.

In their study, Chang and Hwang [21] suggested the use of an AR-based flipped learning approach to improve students' learning skills and critical thinking intentions while working on a scientific project, their learning motivation, and group self-efficacy. The participants consisted of 111 fifth-grade students in four classes. In the experimental group with two classes, students used the AR-based flipped learning setting while the 
control group with the remaining two classes was taught through conventional flipped learning. The experimental results indicated that the AR-based flipped learning setting not only improved students' project-making performances but also improved their learning motivation, critical thinking intentions, and group self-efficacy.

Şahin [22] examined the relationship between the augmented reality practices in science lessons and students' success, attitudes towards the subject matter, and attitudes towards augmented reality practices. The sample of the quasi-experimental research design was made up of 100 seventh-grade students. The data collected from the study revealed a significant difference between the success and attitude towards the lesson of students in the experiment and the control group.

Akçayır, Akçayır, Pektaş, and Ocak [23] studied the effects of the augmented reality content developed for use in science laboratories on first-year university students' laboratory skills and their attitudes towards laboratory activities. A total of 76 students participated in the experimental design with a pre-test post-test control group and it was found that augmented reality practices did not have any positive impact on students' laboratory skills. Additionally, another finding of the study is that students developed positive attitudes towards the activities held at the science laboratories.

Y1ldırım [24] developed two augmented reality applications, named ABCArTablet and $A B C A r P C$, to be used in the Granulated Structure of the Matter unit of the sixth-grade science subject. The study aimed to determine the impact of these applications on students' academic success, motivation, perceptions, and attitudes regarding problem-solving skills. The study consisted of a control group of 50 students and two experimental groups which used the two different augmented reality applications. The study found that while the augmented reality practices had a positive impact on students' interest in the subject and made the lessons more enjoyable; no significant difference was observed between the experiment and control groups in terms of the mean scores of students' perceptions, attitudes, and success scores.

As seen in the literature, the use of AR in science lessons provides real-life experiences and permanent learning by transforming abstract events into concrete examples for the students.

Due to the epidemic spreading all over the world and affecting every field, educational institutions started to use information and communication technology (ICT) to restructure their education systems. In this context, the aim is not only to provide online education, but also to develop different tools to provide lessons' continuation during this epidemic season [25]. In science education, materials gain more importance in transferring the phenomenon and cases that are difficult to introduce in the classroom.

Another important factor for science education is the active participation of the students. The source of information and how it is obtained, evaluated, and used in the problem-solving process are important for ensuring the active participation of students in the learning process [26]. Problem-based learning (PBL) is also an educational approach that aims to increase students' learning capacities and gain the ability to learn to learn. In this approach, groups of less than 8 people are studied and students are expected to solve real-world problems by self-guiding [27]. PBL, which has been widely used in many parts of the world after it became popular in medical schools, has taken part in different applications in science education at different levels from primary education to higher education [28].

Studies in which the PBL approach is applied in science lessons have been examined in the literature. In one of these studies, the effect of the PBL approach on the success and motivation of middle school first-grade students in science lessons was investigated. The study, with 4500 students participating, was designed using a quasi-experimental design. The results of the research showed that the PBL approach is more successful than the traditional approach in positively affecting students' motivation towards the lesson. In addition, it was concluded that the PBL approach is more effective than the traditional approach in increasing student achievement [29]. 
In another study, the effects of the PBL approach on the conceptual understanding, problem-solving skills, and perception levels of pre-service teachers who took the Science Teaching Laboratory Applications I-II course were investigated. In the pre-test post-test control group quasi-experimental research design, the experimental group continued their lessons with the PBL approach, while the control group completed their lessons with the experimental technique. The study revealed that the experimental group students' perception levels of conceptual understanding and creativity differ significantly from the control group students [30].

In the literature review, the PBL approach was found to be an effective teaching method that can be used in science lessons. It has been observed that the effects on motivation, concept learning, creativity, and critical thinking are sought in studies conducted with a problem-based learning approach in science. As a result of the literature survey, no study on the use of the PBL approach with AR technology in science education has been found. In this context, it is hoped that this study will make a significant contribution to the literature.

The main aim of this study is to present student and science teacher views regarding the augmented reality content developed for 7th-grade science education in which the lessons are designed with a PBL approach.

Within the scope of this article, AR content has been developed and integrated into the AR application. Later, the application was used in the science lessons and student and teacher views regarding the AR contents were obtained. The article is composed of the following chapters: Introduction, Methodology, Results, Discussion and Conclusion.

\section{Methodology}

This is a qualitative study that used semi-structured interview forms developed by the researchers as a data collection instrument. A qualitative method is used when a deeper understanding is needed on special cases or when it is required to understand the meaning and preferences behind major patterns [31]. This study aims to investigate student and teacher views in detail regarding the developed AR content. Thus, a qualitative method was preferred.

\subsection{Participants}

The study sample consisted of 80 seventh-grade students and 4 science teachers. Out of the students, whose mean age was 12 years, $51 \%$ were female and $49 \%$ were male students. From the science teachers who participated in the study, $75 \%$ were women and $25 \%$ were men. The application content was developed to be used on tablet computers and the criterion for determining the participants was the availability of tablets in the classroom. For this reason, the participants were determined using a purposive sampling method.

\subsection{Data Collection Tools}

The researchers developed two different semi-structured interview forms to collect student and teacher views regarding the use of AR application in science lessons. Content validity during the preparation of the interview questions was ensured through literature review and expert opinions. Content validity is the scope within which the items of a data collection tool are adequately sampled from the specified content area [32]. Seven experts were consulted to ensure the clarity and appropriateness of the prepared questions and required changes were made on the questions based on the feedback received to finalize the interview forms. Upon implementation, face-to-face interviews were conducted with 25 voluntary students and 4 science teachers. Yildirim and Simsek [33] suggest that interview is a strong method to reveal data, views, experiences, and emotions that belong to individuals.

\subsection{Software Content Development Process}

Animations explaining science subject topics were developed by the researcher as part of the study. The development of the animations was done within the scope of the 
design-based learning model. The design-based learning model aims to find new theories and applications which may bring innovations to teaching and learning. With this method, while different learning styles are designed, continuous assessments are made and shaped based on these results. This feature distinguished the design-based learning model from other traditional design methods. In traditional design methods, an assessment is made after completing product development, then it is presented to the users and the design is completed [34]. The development processes of the animations used as content for the AR application are presented in this section.

Prior to starting the design and implementation part of the study, a needs analysis was conducted to see which topics and objectives the animations in the AR software would cover. The needs analysis was completed with the 5 science teachers working at the school where the study was conducted through an interview form of 5 questions. The data collected from the teachers were used to determine the needs. A total of 15 students who took science in the previous semester were also interviewed in an attempt to see what topics they found challenging.

The results of the needs analysis revealed that the teachers use technological tools such as computers, tablets, projection, and smart boards for their instructional activities. The aims of using tablets in science lessons included rewarding the students, showing videos, conducting virtual experiments, and sharing materials with students. It was seen that the use of AR in science education was mostly needed at the 7th grade due to the large number of abstract topics covered. The topics to be supported with AR technology during learning were determined as "eye", "five sensory organs", "nervous system", "magnets", "acids and bases", "hormones", and "food chain".

At the next stage, the software content was developed based on continuous feedback. During this process, the user-friendliness of the software was evaluated on the basis of teacher and student views. After developing the software content, opinions of five instructional technology experts, three science education experts, and one language expert were received and the content was developed again.

The developed content was integrated into the HP Reveal (Aurasma) application. Thus, the content was made accessible through any mobile device with HP Reveal (Aurasma) installed.

The contents developed according to continuous interviews and assessments were prepared as animations. Each of the animations consisted of three parts and they all started with the introduction part. This part presents two characters (Ada and Mira) who inform students about the topic to be taught. Then, the topic is presented followed by a process indicating that the animation is finished.

\subsection{Implementation}

HP Reveal (Aurasma), with its readily-available mobile application, was used in the study through tablets. HP Reveal (Aurasma) is a platform that enables the integration of animations, videos, 3D models, or websites on authentic images called indicators and through which mobile devices recognize the indicators and help view them with the previously defined images [35].

An informed consent form was sent to parents in order to provide information and obtain their permission regarding the participation of their children in the study while the participants were also orally informed. As the first stage of the implementation, the science teachers of the study group were received training on the augmented reality content developed for the study and the HP Reveal (Aurasma) application. At the next stage, the HP Reveal (Aurasma) application was installed on students' tablets and they were informed about the application followed by a ten-week implementation period in the science lessons.

Animations were prepared on the science topics of "nervous system", "sense organs", "eye structure", "response of the eye to light", "hormones", "magnets", "acids", and "food chain". Stickers containing visuals of each topic were prepared as indicators so that these animations would be viewed by HP Reveal (Aurasma). Adobe Photoshop and Adobe Flash Air CC software were used for this stage. Screenshots of the used application are 
shown in Figure 1. The animations shown in the screenshot in Figure 1 were defined in the stickers also shown in Figure 1. The animations can be viewed by scanning the stickers through a tablet with HP Reveal (Aurasma).
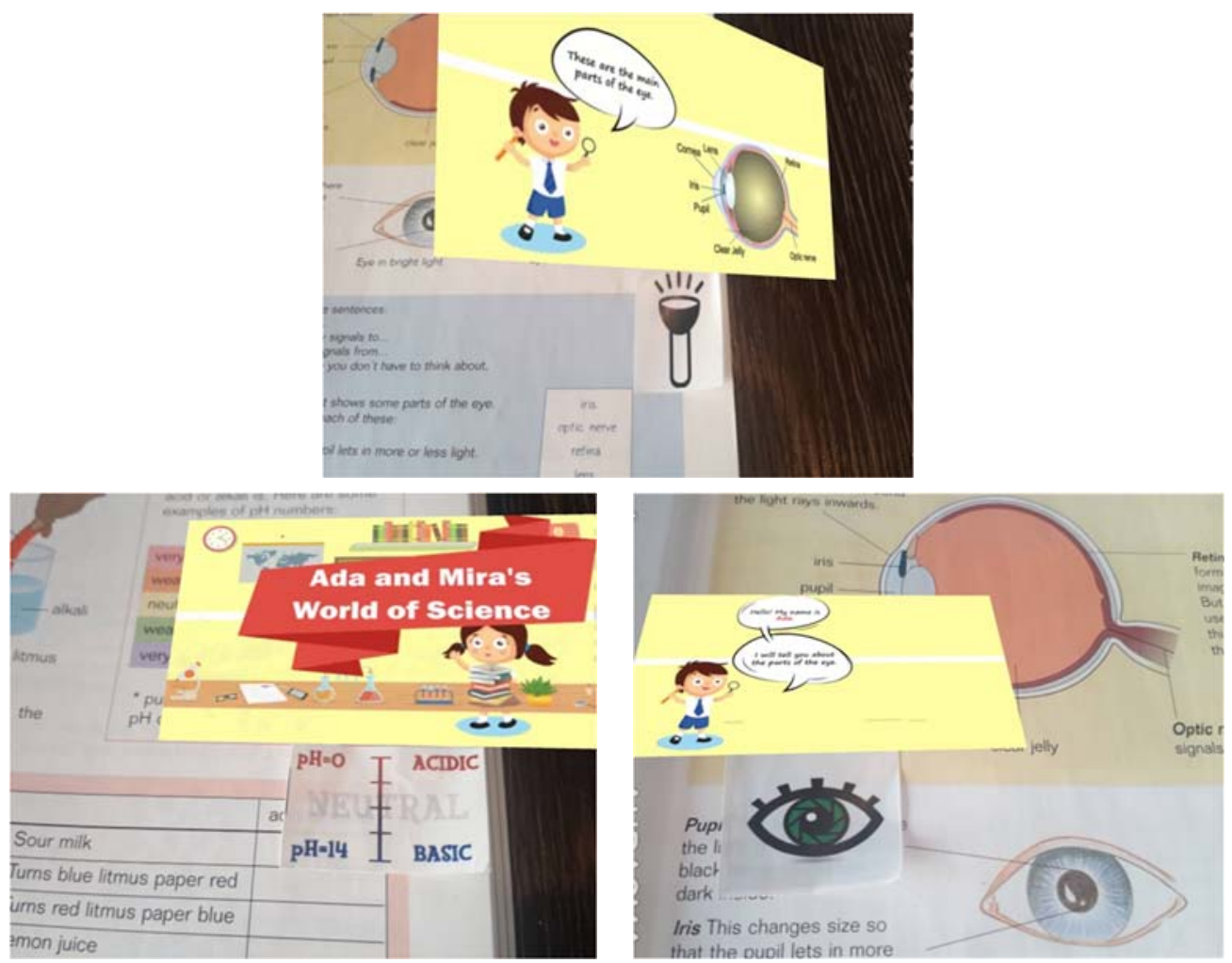

Figure 1. Sample screenshots of AR application.

The stickers prepared within the scope of this study were distributed to the students so that they would stick them to their books when covering the relevant topic. The new topics were covered through a problem-based learning approach. As part of the problembased learning, a real problem case was developed for the classes. The students were separated into groups of 3-5 people. Then, the students shared their previous experiences and knowledge regarding the problem case with each other. The teacher's role included: facilitating the learning process; enabling students' access to instructional materials that ease learning; encouraging students to reflect on their prior experiences and explain the situation. The students have the responsibility of analyzing the situation through discussion and searching for the answers to the questions. The new knowledge and experiences gathered based on the problem are adapted to the problem and the students form their hypotheses [1]. In this regard, the students were assigned to groups of three or four. During implementation, the students tried to solve the problems given to them in collaboration within their group. At the problem-solving stage, they watched the animation through the HP Reveal (Aurasma) to learn the new topic. Upon completion of the tenweek implementation, the 4 teachers and 25 volunteering students were interviewed to determine their views on the AR content.

\subsection{Data Analysis}

Within the scope of the qualitative data analysis, the data from the semi-structured interviews with the teachers and the students were analyzed through descriptive analysis. The reason for choosing descriptive analysis was to be able to present direct excerpts from the findings together with interpretation. The data collected in the descriptive analysis process is summarized and interpreted in line with the previously determined themes. The four stages forming descriptive analysis are: creating the descriptive analysis framework; 
processing the data in line with the thematic framework; describing the findings; and interpreting the findings [33].

A conceptual framework was prepared before analyzing the interviews. The conceptual framework was formed by determining the themes in line with the research questions and the dimensions included in the interviews. Then, the data from the interviews were organized in a meaningful way under the themes and direct excerpts were selected for use. Tables were consulted in organizing the data and the codes and themes were presented in numbers based on their repetition frequency. At the next stage, the organized data was described by providing direct excerpts. The last stage for the analysis of the interviews included the interpretation of the findings by the researcher through the cause-effect relationship.

\section{Results}

\subsection{Student Views Regarding the AR Application}

3.1.1. Student Views Regarding the AR Application before the Implementation

It was aimed to investigate student views regarding the Augmented Reality application before its use in science education. Seven themes were gathered from the students' responses before AR application use. The frequencies of these themes are presented in Table 1.

Table 1. Student Views on AR Application before its Implementation.

\begin{tabular}{cl}
\hline Views & F \\
\hline Easing understanding & 13 \\
\hline Getting excited & 11 \\
\hline Being happy & 7 \\
\hline Being curious & 6 \\
\hline Making the lesson fun & 3 \\
\hline Unnecessary & 3 \\
\hline Permanence of what is learnt & 2 \\
\hline
\end{tabular}

It is seen from the table above that, prior to the AR application use, the majority of the students reported that the AR application would ease the understanding of the science topics. One of the student's views regarding improving understanding is given below:

"We have never used such an application in any of our classes before. We use different methods in our science lessons as compared to the other subjects and we also have laboratory practices. However, when I learnt that we will use an application including animations explaining the topics, I thought it would make it easier to understand the topics and help me learn better". (Student 1)

The quote above shows that some of the students feel excitement towards using the AR application that has not been used before. Another view of a student on this matter is as follows:

"We felt really excited as the whole class and were curious about the new application. Because it would be our first time in following the lesson through Augmented Reality applications". (Student 6)

Some of the students stated that they felt happy to be using the AR application. One of the student's statements about this is presented below:

"I was happy and excited. Because I remember more of what I learnt when I watch visuals and moving visuals such as films. I thought it would make it easier for me to remember the topics". (Student 9)

When Table 1 is reviewed, it is seen that, prior to the use of the AR application in the science lessons, some of the students were curious about the application while others believed that the application would make the lessons more fun. 
Three of the students thought that the use of AR technology in science lessons would be useless. One such view is as follows:

"I do not think there is a need for new applications, we could have followed our lessons in the class and the laboratory as we do every year". (Student 23)

\subsubsection{Student Views Regarding AR Application after the Implementation}

Another aim of this study is to find out about student views regarding augmented reality application after its use in science education. A total of nine different themes were revealed after using the AR application. The frequencies regarding these themes are presented in Table 2.

Table 2. Student Views on AR Application After its Implementation.

\begin{tabular}{cl}
\hline Views & F \\
\hline Easing understandings of the topics & 17 \\
\hline Affecting interaction positively & 13 \\
\hline Affecting permanence positively & 12 \\
\hline Affecting attitudes towards the subject positively & 10 \\
\hline Making the lesson fun & 8 \\
\hline Offering visual topic presentation & 7 \\
\hline Helping topics to be understood in a short time & 6 \\
\hline Affecting study motivation positively & 4 \\
\hline Not affecting communication & 1 \\
\hline
\end{tabular}

As seen in Table 2, following the use of the AR application, the majority of students reported that the AR application made it easier for them to understand the topics covered. One of the student's views regarding this is as follows:

"I understand science topics better this year. Because last year, we did not have many visual materials. We were taking notes in the class, then, studying throughout notes and the books. The animations we have used this year helped us learn the topics better". (Student 3)

Some of the students stated that the AR application affected in-class communication positively. One of the student's views is quoted below:

"I think watching the science animations have affected the classroom setting and communication. Because we were getting closer with our friends as we were continuously discussing the animations. Apart from this, when I or one of my friends did not have a tablet, there were times when we shared our tablet to watch the animations". (Student 7)

Some of the responses from the students showed that the AR technology made it easier to remember the topics covered and positively affected the permanence of what is learned. One of the student's views on this issue is presented below:

"One of the contributions of this application for me is that it made it easier for me to remember the topics. Because it is like the animations summarize the topics from beginning to the end and explain them visually, so what I learn becomes more memorable". (Student 7)

Some of the students said that the AR application positively affects their attitudes towards the science subject; others believe that it made the lessons more fun, and some other students stated that the topics are learned in a shorter period of time. 


\subsubsection{Student Views on the Negative Aspects of the AR Application}

Student views regarding the negative aspects of the AR application used in 7th-grade science education were grouped under five themes. The frequencies for these five themes are presented in Table 3.

Table 3. Student Views on the Negative Aspects of AR Application.

\begin{tabular}{cl}
\hline Views & F \\
\hline Taking long to recognize the indicator & 5 \\
\hline Lack of audio & 4 \\
\hline No problem & 4 \\
\hline Disappearance of the image from the screen with camera movement & 1 \\
\hline Background color & 1 \\
\hline
\end{tabular}

As can be seen from Table 3, most of the students reported that the animations were not immediately viewed as the indicator needed to start the animations in the AR application and it took some time to be recognized. One of the student's views regarding this problem is as follows:

"I had a little problem while opening the animations in the application. It was very difficult to get the stickers recognized, became even more difficult when the classroom was not well-lit and took time to start the animations". (Student 13)

Some of the students concluded that the lack of audio in the animations was a negative feature. A student's view regarding this assessment is given below:

"It could have been more fun if the animations had audio as well". (Student 15)

Some of the students did not report any negative features with the animations. One of the student's views on the lack of any negative features is presented below:

"I did not experience any problems. I used the application with fun and watched the animations with curiosity". (Student 2)

Some of the students evaluated the disappearance of the visual when the tablet is moved during the animations as a negative aspect. This is supported by one of the student's views below:

"The animation disappeared when we moved the camera away from the sticker during the animation. This was making the use of the application difficult". (Student 8)

One of the participating students stated that the background color of the animations was a negative aspect. The student's view is as follows:

"The laboratory section viewed at the beginning of the animation was very good, but the background changed in the other parts and it was very inanimate. I think the background of the animations should have been that laboratory image as well. It would have been more attracting". (Student 15)

\subsection{Teacher Views on the AR Application}

3.2.1. Teacher Views on the Impact of AR Application on Teachers and Science Teaching

It was aimed to determine teachers' views regarding the impact of AR application used in science education on teachers and science education.

Five themes have been formed from the teachers' responses and the frequencies regarding these five themes are presented in Table 4. 
Table 4. Teacher Views on the Impact of AR Application on Teachers and Science Teaching.

\begin{tabular}{cl}
\hline Views & F \\
\hline Attracting attention & 4 \\
\hline Classroom management & 3 \\
\hline Easing topic presentation & 3 \\
\hline Preparation time for the lesson & 2 \\
\hline Affecting communication positively & 2 \\
\hline
\end{tabular}

As can be seen from Table 4, all teachers who participated in the study stated that the use of AR application in the science lessons helped teachers to attract students' attention. One of the teacher's views regarding this issue is given below:

"Students generally have a negative attitude towards the science subject due to past negative experiences and as a result, they do not show interest in the lessons. So, we look for ways to attract their attention throughout the lessons. Hence, using AR application positively helped us both to attract students' attention and increase their attention span". (Teacher 1)

While some of the teachers stated that the use of the AR application positively affects classroom management, there is only one teacher who reported that the application caused problems in classroom management. Some of the teachers' views regarding these aspects are presented below:

"I believe that trying to keep the students at the same place and ask them to constantly repeat the same activity such as taking notes with the traditional methods does not provide an effective educational setting as well as making classroom management difficult. After we started using the AR application, students' interest, motivation and participation in the activities have increased so; I can say that classroom management became easier for me". (Teacher 4)

"The AR application had a negative impact on the management of my classrooms. Because previously, there was a setting where students were taking notes in their notebooks without much communication. Making a sudden change in the classroom arrangement caused movements in the class. Students were active when using the AR application and it was difficult for me to control the class". (Teacher 2)

A part of the teachers' responses indicated that it was easier for them this semester to transfer the new topics to the students through the AR application. One of such views is as follows:

"Thanks to AR, I was not the primary source of the topic to be covered anymore. I was only facilitating students' learning. In short, AR application helped me to transfer the topics to the students with the help of its age-appropriate content". (Teacher 2)

While some of the teachers reported that their lesson preparation time decreased with the use of the AR application; others stated that using the AR application positively affected their in-class communication with the students.

3.2.2. Teacher Views on the Impact of the AR Application on Students and Science Learning

As part of the study, it was also aimed to investigate the teachers' views regarding the impact of the AR application on students and science learning. Seven different themes were gathered from the teachers' responses. The frequencies of these themes are presented in Table 5. 
Table 5. Teacher Views on the Impact of AR Application on Students and Science Learning.

\begin{tabular}{cl}
\hline Views & F \\
\hline Encouraging learning & 4 \\
\hline Affecting permanence positively & 4 \\
\hline Affecting attitude towards the subject positively & 3 \\
\hline Learning by fun & 3 \\
\hline Affecting communication positively & 3 \\
\hline Visual topic presentation & 3 \\
\hline Distancing from memorizing & 1 \\
\hline
\end{tabular}

The table above shows that all the teachers stated that the use of AR application in science lessons encourages learning. One of these views is given below:

"I can comfortably say that the AR application which can be used anywhere not only at school is a material that allows students to gain new knowledge and experience". (Teacher 4)

All of the teachers reported that the AR application used in science lessons has a positive influence on the permanence of what is learned. Teachers' views regarding the impact of the AR application on the permanence of learning is as follows:

"Topics learnt by using different materials is always more memorable. Science education includes mostly abstract topics and we cannot make sure that students learn the topics only with our explanations. Thus, we pay attention to using different materials in our lessons as much as possible. AR application has ensured that the topics learnt are more permanent. Because the topics are covered fully through visual components and by animations". (Teacher 1)

Most of the teachers believe that with the AR application, students' attitudes towards the lesson are affected positively. One such teacher's view is presented below:

"Students always start the science education with a prejudice. This is because students are previously taught to constantly take notes, not learn the topics in class and accumulation of a lot of topics during exam time and explanation of these topics only in writing. It was very difficult for us to overcome this prejudice. I observed that the negative prejudice of the students' were resolved as soon as the semester started with the use of the AR application". (Teacher 3)

The majority of teachers responded that the AR application enables learning fun Additionally, some of the teachers' responses showed that the use of the AR application made a positive contribution to the communication among students. Another group of teachers stated that the use of AR in science lessons enables a visual topic introduction for the students.

\subsubsection{Teacher Views on the Negative Aspects of the AR Application}

The responses regarding teachers' views on the negative aspects of the AR application used in 7th-grade science education are collected under three themes. The frequencies for these three themes are presented in Table 6.

Table 6. Teacher Views on the Negative Aspects of the AR Application.

\begin{tabular}{cl}
\hline Views & F \\
\hline Taking long to recognize the indicator & 4 \\
\hline Disappearance of the image from the screen with camera movement & 3 \\
\hline Lack of audio & 1 \\
\hline
\end{tabular}


As can be seen in Table 6, all of the teachers reported that the contents cannot be immediately viewed as it takes time to recognize the indicator needed to start the contents in the AR application. A teacher's statement on this matter is given below:

"We have had problems in starting the content while using the AR application. We spend a lot of time on the camera recognizing the indicators. The difference of lightning at different points within the classroom affected this as well". (Teacher 1)

Most of the teachers concluded that the disappearance of the visual from the screen when the tablet is moved during the animation was a negative aspect. One of the teacher's views regarding this opinion is as follows:

"The content was viewed after getting the stickers in the books recognized by the AR application through the cameras. The tablet was not to be moved away from the indicator during viewing. Because even with the slightest movement of the camera the visual was disappearing and content was viewed only after getting the indicator recognized by the application again. Students were not able to continue to the content from where they stopped; they started watching from the beginning. I think it was a negative aspect that the application was sensitive to camera movement". (Teacher 2)

One of the teachers suggested that the lack of audio features was a negative aspect of the AR application. The following comment is from that teacher:

"Generally, the animations or moving images students watch have audio feature. The contents of the AR application did not have an audio feature and its lack was felt during watching. An audio feature should have been added to give students the right to control turn on and off the volume. Students could have watched the content with audio at home and even, used earphones to use the audio in the classroom setting". (Teacher 4)

\section{Discussion and Conclusions}

Augmented reality (AR) is a technology that allows changes to reality by combining real-world images with digital factors and improves the perception of reality. The AR application content developed as part of this study was used in 7th-grade science education. According to the findings of the study, it was seen that both students and teachers report mostly positive views regarding augmented reality practices.

The data from the student interviews show that the students believed that AR application encouraged learning, enabled the visual introduction of the topics, and ensured the topic introduction in a short time. The findings of this study confirm the conclusion that students have positive attitudes towards AR-supported learning activities from Lu and Liu's [36] study.

It was found in this study that the AR application used in the lessons enables visual topic presentation, improves the understanding of topics, helps understand topics in a short time, and has positive effects on students' motivation towards the subject as well as students' examination scores. In parallel to this finding, other studies also suggest that AR technology provides information directly serving the aim and offers guidance in a way that increases students' motivation [21,37].

It was concluded that the AR application used in this study allows a better understanding of the topics and positively affects the permanence of the topics covered. These findings support Yoon et al.'s [38] results indicating that AR components such as video and 3D images enable students to understand the content better.

The majority of student views indicate that the AR application had a positive impact on the in-class interaction for the duration of the lesson. This result supports the findings from other studies suggesting that AR materials have positive effects on the interaction during the class. In their study, Kamarainen et al. [39] put forward that AR technology supports the increase of interaction between students. Likewise, Dunleavy et al. [40] suggested that mobile AR technology eases collaborative learning in hybrid learning settings combining digital and physical objects. 
All the teacher views gathered in this study report that the augmented reality applications used in the lessons were helpful in attracting students' attention and increasing their attention span throughout the lesson. It was seen that this finding is in parallel with the results of the study conducted by Zhang, Sung, Hou, and Chang [41].

Some of the teacher views include that the augmented reality application helps teachers in transferring new topics to the students, reduces lesson preparation time, and positively affects the interaction with students. Similarly, Zarraonandia, Aedo, Díaz, and Montero [42] found that augmented reality technology increases the communication and interaction between teachers and students.

Another finding from the teachers' views in the study is that the augmented reality application encourages learning, enables visual topic introduction, increases the permanence of the topics learned, contributes to learning by fun, and positively affects attitudes towards the subject. Students become more enthusiastic in their learning process. Similarly, Chiang et al. [43] stated in their study that the augmented reality application supports students' learning of the topic and transfers the information to the students in a short time.

Despite the many advantages that AR technology brings to educational settings, there are also negative findings regarding the use of the AR application in the study. The students and the teachers who participated in this study, reported that they experienced problems with the stickers, known as indicators in the augmented reality technology while getting them recognized by the camera and the software. It was seen that being in a not well-lit setting and physical damaging of the stickers on the books, such as creasing or scoring, during the definition of the indicators increase the problem of recognition. This finding confirms Cheng and Tsai's [37] conclusion of a low sensitivity problem in recognizing indicators from their study.

Another major deficiency of the implementation is the lack of audio on the AR application. Both the students and the teachers reported that the application would become more attractive and easier to follow with the addition of audio features. This outcome is in parallel with the student views regarding an AR application without audio from the study conducted by Akçayır, Akçayır, Pektaş, and Ocak [23]. It is suggested for future studies to design augmented reality contents with audio features and to add a user control to the audio feature.

Funding: This research received no external funding.

Institutional Review Board Statement: The study was conducted according to the guidelines of the Declaration of Helsinki, and approved by the Ethics Committee of Near East University.

Informed Consent Statement: Informed consent was obtained from all subjects involved in the study.

Data Availability Statement: Data is contained within the article.

Conflicts of Interest: The author declares no conflict of interest.

\section{References}

1. Kaptan, F.; Korkmaz, H. Fen eğitiminde probleme dayalı öğrenme yaklaşımı (Problem-based learning approach in science education). Hacet. Univ. J. Educ. Fac. 2001, 20, 185-192.

2. Güçlüer, E. İlköğretim fen bilgisi eğitiminde kavram haritaları ile verilen bilişsel desteğin başarıya, hatırda tutmaya ve fen bilgisi dersine ilişkin tutuma etkisi (The Effect of Cognitive Support Given with Concept Maps in Elementary Science Education on Achievement, Remembering and Attitude towards Science Lesson). Ph.D. Thesis, DEU Institute of Educational Sciences, Izmir, Turkey, 2006.

3. Akpınar, E. Buluş stratejisiyle enerji ilişkili fen öğretimi: Canlılar için madde ve enerji ünitesi (Energy-Related Science Teaching with Discovery Strategy: The Unit of Matter and Energy for Living Things). Ph.D. Thesis, DEU Institute of Educational Sciences, Izmir, Turkey, 2003.

4. Fensham, P.J.; Gunstone, R.F.; White, R.T.; White, R.T. The Content of Science: A Constructivist Approach to Its Teaching and Learning; Psychology Press: London, UK, 1994.

5. Şahin, F.; Oktay, A. İlkokullarda hücre solunumu ile ilgili kavramsal değişim (Conceptual change regarding cell breathing in primary schools). Marmara Univ. Atatürk Fac. Educ. J. Educ. Sci. 1996, 8, 227-236.

6. Kilic, A. Learner-Centered Micro Teaching in Teacher Education. Online Submiss. 2010, 3, 77-100. 
7. Ünal, G.; Ergin, Ö. Buluş yoluyla fen öğretiminin öğrencilerin akademik başarılarına, öğrenme yaklaşımlarına ve tutumlarına etkisi (The effect of discovery science teaching on students' academic achievement, learning approaches and attitudes). J. Turk. Sci. Educ. 2006, 3, 36-52.

8. Abu-Al-Aish, A.; Love, S. Factors influencing students' acceptance of m-learning: An investigation in higher education. Int. Rev. Res. Open Distrib. Learn. 2013, 14, 82-107. [CrossRef]

9. Alghazi, S.; Kamsin, A.; Almaiah, M.; Wong, S.; Shuib, L. For Sustainable Application of Mobile Learning: An Extended UTAUT Model to Examine the Effect of Technical Factors on the Usage of Mobile Devices as a Learning Tool. Sustainability 2021, 13, 1856. [CrossRef]

10. Nincarean, D.; Alia, M.B.; Halim, N.D.A.; Rahman, M.H.A. Mobile Augmented Reality: The Potential for Education. Procedia Soc. Behav. Sci. 2013, 103, 657-664. [CrossRef]

11. Zachary, W.; Ryder, J.; Hicinbothom, J.; Bracken, K. The Use of Executable Cognitive Models in Simulation-Based Intelligent Embedded Training. In Proceedings of the Human Factors and Ergonomics Society Annual Meeting; SAGE Publications: New York, NY, USA, 1997; Volume 41, pp. 1118-1122.

12. Ozdamli, F.; Karagözlü, D. Preschool Teachers' Opinions on the Use of Augmented Reality Application in Preschool Science Education/Mišljenja nastavnika predškolskog odgoja o upotrebi aplikacije proširene stvarnosti u predškolskom obrazovanju u području prirodnih znanosti. Croat. J. Educ. Hrvat. Časopis za odgoj I Obraz. 2018, 20, 43-74. [CrossRef]

13. Wu, H.-K.; Lee, S.W.-Y.; Chang, H.-Y.; Liang, J.-C. Current status, opportunities and challenges of augmented reality in education. Comput. Educ. 2013, 62, 41-49. [CrossRef]

14. Goff, E.E.; Mulvey, K.L.; Irvin, M.J.; Hartstone-Rose, A. Applications of Augmented Reality in Informal Science Learning Sites: A Review. J. Sci. Educ. Technol. 2018, 27, 433-447. [CrossRef]

15. Cai, S.; Wang, X.; Gao, M.; Yu, S. Simulation Teaching in 3D Augmented Reality Environment. In Proceedings of the 2012 IIAI International Conference on Advanced Applied Informatics, Fukuoka, Japan, 20-22 September 2012; pp. 83-88.

16. Cai, S.; Chiang, F.K.; Wang, X. Using the augmented reality $3 \mathrm{D}$ technique for a convex imaging experiment in a physics course. Int. J. Eng. Educ. 2013, 29, 856-865.

17. Ibáñez, M.B.; Di Serio, Á.; Villarán, D.; Kloos, C.D. Experimenting with electromagnetism using augmented reality: Impact on flow student experience and educational effectiveness. Comput. Educ. 2014, 71, 1-13. [CrossRef]

18. Sahin, D.; Yilmaz, R.M. The effect of Augmented Reality Technology on middle school students' achievements and attitudes towards science education. Comput. Educ. 2020, 144, 103710. [CrossRef]

19. Karagozlu, D.; Kosarenko, N.N.; Efimova, O.V.; Zubov, V.V. Identifying Students' Attitudes Regarding Augmented Reality Applications in Science Classes. Int. J. Emerg. Technol. Learn. (iJET) 2019, 14, 45-55. [CrossRef]

20. Georgiou, Y.; Kyza, E.A. Relations between student motivation, immersion and learning outcomes in location-based augmented reality settings. Comput. Hum. Behav. 2018, 89, 173-181. [CrossRef]

21. Chang, S.-C.; Hwang, G.-J. Impacts of an augmented reality-based flipped learning guiding approach on students' scientific project performance and perceptions. Comput. Educ. 2018, 125, 226-239. [CrossRef]

22. Şahin, D. Artırılmış Gerçeklik Teknolojisi ile Yapılan Fen Öğretiminin Ortaokul Öğrencilerinin Başarılarına ve Derse Karşı Tutumlarına Etkisi (The Effect of Science Instruction with Augmented Reality Technology on Secondary School Students' Achievement and Attitudes Towards the Course). Master's Thesis, Atatürk University, Erzurum, Turkey, 2017.

23. Akçayır, M.; Akçayır, G.; Pektaş, H.M.; Ocak, M.A. Augmented reality in science laboratories: The effects of augmented reality on university students' laboratory skills and attitudes toward science laboratories. Comput. Hum. Behav. 2016, 57, 334-342. [CrossRef]

24. Yıldırım, S. Fen Bilimleri Dersinde Artırılmış Gerçeklik Uygulamalarının Öğrencilerin Başarısına, Motivasyonuna, Problem Çözme Becerilerine Yönelik Algısına ve Tutumlarına Etkisi (The Effect of Augmented Reality Applications in Science Course on Students' Achievement, Motivation, Perception and Attitudes Towards Problem Solving Skills). Master's Thesis, Ankara University, Ankara, Turkey, 2016.

25. Quadir, B.; Zhou, M. Students Perceptions, System Characteristics and Online Learning During the COVID-19 Epidemic School Disruption. Int. J. Distance Educ. Technol. 2021, 19, 1-19. [CrossRef]

26. Van Til, C.T. Problem-based Learning Behavior: The Impact of Differences in Problem-Based Learning Style and Activity on Students' Achievement; American Educational Research Association: Chicago, IL, USA, 1997.

27. Ngeow, K.; Kong, Y.S. Learning to Learn: Preparing Teachers and Students for Problem-Based Learning. ERIC Digest. 2001. Available online: https:/ / eric.ed.gov/?id=ED457524 (accessed on 22 May 2021).

28. Tosun, C.; Yaşar, M. Comparison of problem-based learning studies in science education in Turkey with the world: Content analysis of research papers. Asia-Pac. Forum Sci. Learn. Teach. 2013, 14, 1-30.

29. Omaga, J.O.; Iji, C.O.; Adeniran, S.A. Effect of problem-based learning approach on secondary school students'interest and achievement in electricity in bauchi state, nigeria. JOSTE 2017, 5, 63-70.

30. Kanar, A. Fen Ogretimi Laboratuvar Uygulamaları Dersinde Probleme Dayalı Ogrenme Yönteminin Kullanılmasının Ogretmen Adayları Uzerindeki Etkilerinin Incelenmesi (Investigation of the Effects of Problem-Based Learning Method on Pre-service Teachers in Science Teaching Laboratory Applications Course). Master's Thesis, Usak University, Usak, Turkey, 2017.

31. Berg, B.L.; Lune, H. Sosyal bilimlerde nitel araştırma yöntemleri (Qualitative Research Methods in the Social Sciences); Eğitim Publishing House: Konya, Turkey, 2019. 
32. Cronbach, L.J.; Thorndike, R.L. Test Validation. In Educational Measurement; American Council on Education: Washington, DC, USA, 1971; pp. 443-507.

33. Yıldırım, A.; Şimşek, H. Sosyal bilimlerde nitel araştırma yöntemleri (Qualitative Research Methods in the Social Sciences); Seçkin Publishing: Ankara, Turkey, 2013.

34. Brown, A.L. Design Experiments: Theoretical and Methodological Challenges in Creating Complex Interventions in Classroom Settings. J. Learn. Sci. 1992, 2, 141-178. [CrossRef]

35. Bondarenko, O.V.; Pakhomova, O.V.; Zaselskiy, V.I. The use of cloud technologies when studying geography by higher school students. arXiv 2019, arXiv:1909.04377.

36. Lu, S.-J.; Liu, Y.-C. Integrating augmented reality technology to enhance children's learning in marine education. Environ. Educ. Res. 2014, 21, 525-541. [CrossRef]

37. Cheng, K.H.; Tsai, C.C. Affordances of augmented reality in science learning: Suggestions for future research. J. Sci. Educ. Technol. 2013, 22, 449-462. [CrossRef]

38. Yoon, S.A.; Elinich, K.; Wang, J.; Steinmeier, C.; Tucker, S. Using augmented reality and knowledge-building scaffolds to improve learning in a science museum. Int. J. Comput. Collab. Learn. 2012, 7, 519-541. [CrossRef]

39. Kamarainen, A.M.; Metcalf, S.; Grotzer, T.; Browne, A.; Mazzuca, D.; Tutwiler, M.S.; Dede, C. EcoMOBILE: Integrating augmented reality and probeware with environmental education field trips. Comput. Educ. 2013, 68, 545-556. [CrossRef]

40. Dunleavy, M. Design Principles for Augmented Reality Learning. TechTrends 2014, 58, 28-34. [CrossRef]

41. Zhang, J.; Sung, Y.-T.; Hou, H.-T.; Chang, K.-E. The development and evaluation of an augmented reality-based armillary sphere for astronomical observation instruction. Comput. Educ. 2014, 73, 178-188. [CrossRef]

42. Zarraonandia, T.; Aedo, I.; Díaz, P.; Montero, Á. An augmented lecture feedback system to support learner and teacher communication. Br. J. Educ. Technol. 2013, 44, 616-628. [CrossRef]

43. Chiang, T.H.; Yang, S.J.; Hwang, G.J. An augmented reality-based mobile learning system to improve students' learning achievements and motivations in natural science inquiry activities. J. Educ. Technol. Soc. 2014, 17, 352-365. 